\title{
Correlation between Chemical Characterization and Treatment Efficiencies of Complex Organic Carbon as Single Substrate in Treating Acid Mine Drainage
}

\author{
R. P. Choudhary
}

\begin{abstract}
To develop efficient passive acid mine drainage (AMD) treatment systems, the anaerobic sulphate reduction process must be optimized, by selecting the most appropriate organic electron donors for sulphate reduction. The effectiveness in the remediation of AMD is dependent on the chemical characterization of organic carbon. Selection of the suitable carbon source is important to ensure performance and longevity of AMD treatment. The objective of the present study is to characterized a few natural organic easily available with almost negligible cost. Ten natural waste materials (i.e. organic waste goat manure, cow manure and buffalo manure and cellulosic waste sugarcane waste, babool woodchip and sawdust, mango woodchips and sawdust, fodder pearl and proso) were tested as single substrate in bench scale bioreactors. The suitability of a substrate for treating a particular substrate was determined empirically using laboratory scale test. Using ten single substrate bioreactors important contaminants removal ( $\mathrm{pH}$ and sulphate) were observed and find their correlation between contaminant removal and chemical characteristics. The study indicates that a wide range of organic substrate materials can be used to effectively treat AMD using SRB technology. Goat, cow and buffalo manures show promising results in the initial startup of the bioreactor. Remove contaminants efficiently.
\end{abstract}

Keywords-AMD, organic substrate, characterization, sulphate removal.

\section{INTRODUCTION}

A major environmental concern currently being faced by active and inactive mining industries throughout the world is the treatment of AMD. The seepage of such acidic discharges resulting from chemical and biological oxidation of residual minerals into the water system constitutes a potential risk to natural ecosystems. The focus of passive mine drainage treatment systems is to apply bio-geochemical water treatment mechanism at or near the source of the mine drainage to concentrate and immobilize metals and raise $\mathrm{pH}$. These systems were filled with peat or other organic substrates. It is now known that mushroom compost as well as other organic substrates, serve to supply sulphate reducing bacteria, like desulfovibrio and desulfotomaculum, with an organic substrate (Siefert and Mutz, 2001). They then can reduce sulphate to sulphides that react with metals to form metal sulphides and

Department of Mining Engineering, National Institute of Technology Karnataka, Mangalore, India-575025, hydrogen sulphides. Other bacteria assist in raising the system $\mathrm{pH}$ to more neutral levels.

The Bioreactor referred to as 'substrate' usually serves two purposes: to provide a carbon source and to maintain flow through the system.Sulphate-reducing bacteria use the easily degradable fraction of organic matter such as low molecular weight compounds with simple structures (e.g., methanol, ethanol, lactate) (Dvorak et al., 1992; Tsukamoto et al., 2004), polylactic acid (Edenborn, 2004), simple carbohydrate monomers (e.g., glucose or sucrose) (Mizuno et al., 1998), and whey (Christensen et al., 1996). In terms of energy and biomass produced, lactate is a superior electron donor compared to others such as ethanol, acetic acid, propionate, and acetate (Nagpal et al., 2000). In terms of moles of bicarbonate produced per mole of substrate consumed, the lactate-utilizing processes are superior to ethanol-utilizing processes since they are better at neutralizing the acidity in the treated effluent (Kaksonen et al., 2004). The main drawback is that only certain species of SRBs (Desulfotomaculum) are capable of oxidizing lactate and ethanol to $\mathrm{CO}_{2}$, whereas others (Desulfovibrio) can partially oxidize the $\mathrm{C} 2-\mathrm{C} 4$ organic carbon molecules to acetate, and very few can use acetate alone (Desulfoto maculum acetoxidans) (Nagpal et al., 2000).

Indirect/complex organic substrates are those requiring decomposition by other microorganisms to provide SRBs nutrition. These substrates require complex microbial communities to degrade the organic matter and support SRB growth. Indirect substrates are more feasible than direct substrates for low maintenance systems at remote mine sites requiring more long-term operation (Sheoran et al., 2010).

Careful selection of suitable carbon source is of paramount importance to ensure performance and longevity in AMD treatment. Bacterial Sulphate reduction has been identified as a potential valuable process for removing contaminant metals from mine drainage under anaerobic conditions; the process can remove metal from solution as insoluble metal sulphides (Dvorak et al, 1992).

Various waste materials could support bacterial Sulphate reduction in compost bioreactor to treat AMD. There is growing evidence that sulphate reduction efficacy can be augmented by the use of natural organic substrate mixtures versus single substrate (Cocos et al, 2002; Amos and Younger, 2003). 
The challenge for having an efficient on-site bioreactor is to select a suitable organic substrate to make the process efficient and economically feasible. Selection of the organic carbon source is usually made on the basis of chemical characterization, availability and costs of the added electron donor per unit of reduced sulphate. The remaining contaminants in the treated water must be present in low concentrations or easy to remove (Hulshoff Pol et al., 2001, ).

The proposed study indicates that a wide range of cheaper and abandoned organic substrate materials can be used to effectively treat AMD using SRB technology. The suitability of a various substrates for treating a particular composition of AMD is best determined empirically using laboratory-scale tests. Also chemical characterization of the substrates on an individual basis provided insight on their organic carbon composition and solubility. It gives a goodidea of ability to promote sulphate reduction.

\section{MATERIALS AND METHOD}

\section{A. Indirect Organic Substrate}

In the present study following cellulosic waste and organic waste used as single substrate in the bioreactors: Cow Manure, Buffalo Manure, Goat Manure, Babool woodchips, Babool sawdust, Mango woodchips, Mango sawdust, Sugarcane waste, Fodder-pearl millet, Fodder proso millet (Fig. 1). The substrates were considered to be potentially suitable with respect to techno-economic characteristics and commercial availability (Beaulieu et al., 2000; Benner et al., 1997).

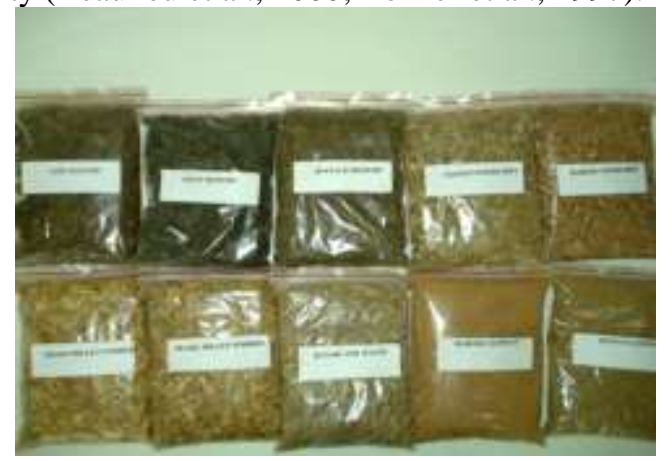

Fig. 1: Various organic substrates used in the experiments

\section{B. Sulphate Reducing Bacteria Inoculums}

In these experiments, however, whey was used to stimulate SRB activity in all the bioreactors. It was collected from local dairy house, Jodhpur at zero or negligible cost. In the present experiment substrate was inoculated with $100 \mathrm{ml}$ of whey. Whey contains fermentable water-soluble proteins, lactose, and lactic acid. The fermentation products and lactic acid supply SRB with a suitable carbon and energy source. Fresh cow manure obtained from a local farm was used as inoculums in all the reactors. Fresh cow manure has been previously found to contain SRB (Christensen et al, 1996).

\section{Synthetic AMD Generation}

Simulated acid mine water was prepared in the laboratory taking into account the usual composition of AMD from metal mining industry. Simulated AMD composition was prepared in 500 litres storage plastic tank for bench scale experiments. The
$\mathrm{pH}$ was adjusted with $\mathrm{H}_{2} \mathrm{SO}_{4}$. All the chemicals were of analytical reagent grade. The composition is given in table 1 .

TABLEI: COMPOSITION OF SYNTHETIC AMD FOR EXPERIMENTAL SETUP

\begin{tabular}{lrcl}
\hline S.No. & Component & Concentration $(\mathrm{mg} / \mathrm{L})$ & \multicolumn{1}{c}{ Source } \\
\hline 1 & $\mathrm{Fe}$ & 188.9 & $\mathrm{FeSO}_{4} .7 \mathrm{H}_{2} \mathrm{O}$ \\
2 & $\mathrm{Cu}$ & 22.21 & $\mathrm{CuSO}_{4} .5 \mathrm{H}_{2} \mathrm{O}$ \\
3 & $\mathrm{Zn}$ & 21.44 & $\mathrm{ZnSO}_{4} .7 \mathrm{H}_{2} \mathrm{O}$ \\
4 & $\mathrm{Mn}$ & 31.87 & $\mathrm{MnSO}_{4} \cdot \mathrm{H}_{2} \mathrm{O}$ \\
5 & $\mathrm{Ni}$ & 10.43 & $\mathrm{NiSO}_{4} \cdot 6 \mathrm{H}_{2} \mathrm{O}$ \\
6 & $\mathrm{Co}$ & 1.24 & $\mathrm{CoSO}_{4} .7 \mathrm{H}_{2} \mathrm{O}$ \\
7 & Sulphate & $4132-4960$ & ----- \\
8 & $\mathrm{pH}$ & $2.70-3.35$ & ---- \\
\hline
\end{tabular}

\section{Experimental Procedure}

Ten bench scale bioreactors were constructed from 1 liter transparent narrow mouth glass bottles provided with inlet at the top and outlet at lower part. The base of the reactor was filled with pebbles of about $5 \mathrm{~mm}$ size up to $25 \mathrm{~mm}$ height (to increase the porosity and to provide the solid surface to SRB's) and each one was filled with different single substrate with $500 \mathrm{cc}$. Then each bioreactor was inoculated with $100 \mathrm{ml}$ whey and 5 gmof fresh cow manure. The inoculated reactors were allowed to stand for an incubation period of 30 days (for proper development and multiplication of SRBs). After incubation period, leading to the development SRBs as visible in the form of black film layer and also strong smell of $\mathrm{H}_{2} \mathrm{~S}$, the bioreactors were supplied with simulated AMD and the flow rate was controlled by I-V set used at outlet (Fig. 2).

Fig. 2: Schematic Diagram of experimental setup for bench scale single substrate bioreactors

After incubation period of 30 days to acclimatize SRBs to the conditions prevailing in bioreactors, outflow of the water was allowed continuously for 10 days and then the samples were analyzed. For the initial 10 days period, the water was just drained out without any observation, as it contained excess of easily soluble fraction of the substrate. So as to avoid any pseudo results it was decided to drain off the water for the first

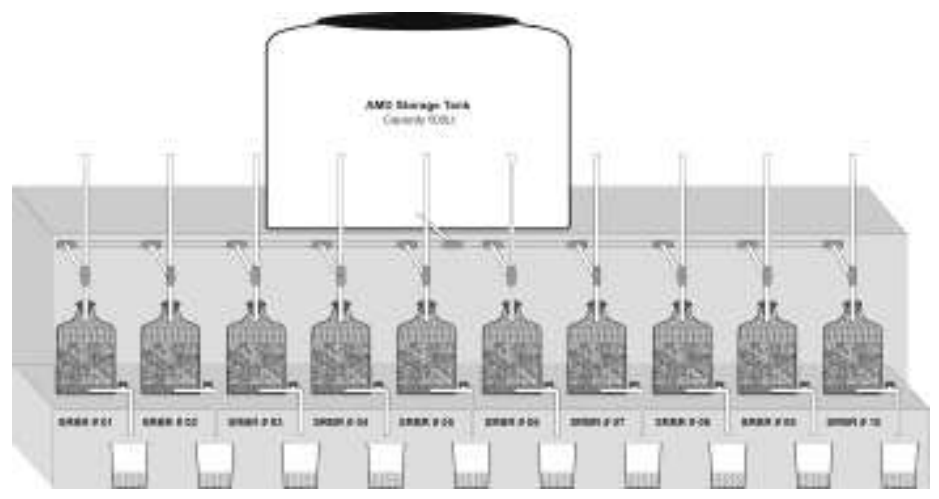

10 days. Sampling and analysis of inlet and out let of each bioreactor was carried out after this, continuously for nine months.

All reactors were ready for observations after 40 days, than samples of inlet and outlets were taken and analyzed for $\mathrm{pH}$ and Sulphate ions. Data were generated to evaluate the performance of each substrate so that selected ones can be used in the next set of experiment.

The samples of inlet and outlet of each bioreactor were taken after a retention period of 1 day, 3 days, 5 days, 7 days and 10days. This cycle was repeated four times, thus 
completing one cycle in 26 days. Than the reactors were closed, means no sampling was carried out for next 15 days. After 15 days, again sampling was carried out and analyzed for 1 day, 3 days, 5 days, 7 days and 10 days retention period. The experimental system was run for about 9 months.

\section{ANALYTICAL TeChNiQues}

$\mathrm{pH}$ was measured with a $\mathrm{pH}$ meter and combination $\mathrm{pH}$ electrode, after a two point calibration (Make- RI, New Delhi, Model 151R) using method $4500-\mathrm{B}$ as detailed in Standard Methods for the examination of Water and Waste Water (APHA, 1992).

Chemical characterization of the organic substrates: Representative sub-samples of all the organic substrates were taken and subjected to the analyses of moisture, dry matter and organic matter. For the complete characterization each substrate was milled in a Wiley mill with a $1 \mathrm{~mm}$ sieve. This milling eliminates any effects that could be caused by the difference in particle size.

Neutral detergent fibre (NDF) and Cell Contents (CC): The Neutral detergent fibre (NDF) or cell wall constituents (CWC) are a component of the organic substrates, which are not soluble in hot, neutral sodium lauryl sulphate solution $(\mathrm{pH}$ : appox. 7) was determined according to Van Soest\& Moore (1965).

Acid detergent fibre (ADF): ADF, lignin, cellulose and silica contents were determined by the method of successive extractions described by Van Soest\& Moore (1968).

Organic matter $(\mathrm{OM})$ : organic matter was determined in accordance with procedures outlined in Standard Methods (APHA, 1992).

Nitrogen \& protein: Crude protein content of samples can be determined by Kjeldahl method using Tecator'sKjeltec system.

Ether extractives: Petroleum ether extracts the fats, oils and waxes along with the green plant pigments like chlorophyll. This parameter of the substrate is important as it can be correlated to the energy (that the substrate can provide) and hence their concentration in the sample is important. Ether extractives are extracted from the samples by repeated refluxing with light petroleum. Later petroleum ether is evaporated off and the amount of extracted materials is gravimetrically determined.

Total carbohydrate and Gross energy: carbohydrate, protein and ether extractives cumulatively represent the various fractions of organic matter. Carbohydrate is calculated by subtracting protein and ether extractives from organic matter. Similarly gross energy is derived from the various components of organic matter like protein, ether extractives and total carbohydrate.

\section{RESUlts AND DisCUSSION}

Performance of each reactor has been monitored regularly by sampling of the influent and effluent. Samples have been analyzed for sulphate and $\mathrm{pH}$. Bench scale tests were conducted to evaluate the performance of single substrate, especially adapted to high metal concentrations and thus, can be recommended to be used in bioremediation processes. Results of the $\mathrm{pH}$ and sulphate change are shown in the following figure 3 . The results revealed efficient removal of the sulphate in manure containing reactors, cellulosic waste under perform as single substrate due to their slow degradation rate.

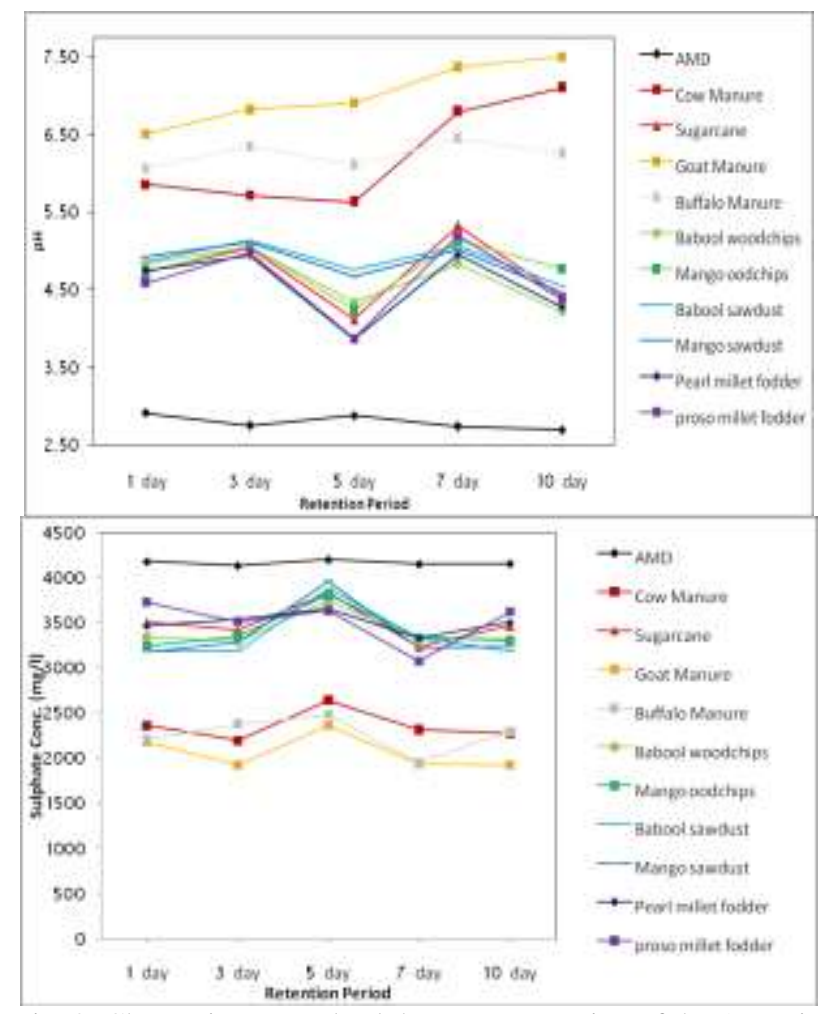

Fig. 3: Change in $\mathrm{pH}$ and sulphate concentration of the AMD in bench scale bioreactors with different retention period (after 9 months) 
TABLE II: CHEMICAL COMPOSITION OF SINGLE SUBSTRATE USED IN BIOREACTORS

\begin{tabular}{lcccccccccccc}
\hline & Moisture & $\begin{array}{c}\text { Dry } \\
\text { matter }\end{array}$ & $\begin{array}{c}\text { Organic } \\
\text { matter }\end{array}$ & Mineral & Nitrogen & Protein $\begin{array}{c}\text { Ether } \\
\text { extrac- } \\
\text { tives }\end{array}$ & $\begin{array}{c}\text { Percent } \\
\text { C }\end{array}$ & $\begin{array}{c}\text { C/N } \\
\text { Total } \\
\text { carbo- } \\
\text { hydrate }\end{array}$ & $\begin{array}{c}\text { Gross } \\
\text { energy } \\
\text { (kcal/ } \\
100 \mathrm{gm})\end{array}$ \\
\hline Cow manure & 3.13 & 96.87 & 40.28 & 59.72 & 1.016 & 6.35 & 1.45 & 23.36 & 23.00 & 32.48 & 184 \\
Sugarcane waste & 5.89 & 94.11 & 93.93 & 06.07 & 0.634 & 3.96 & 2.10 & 54.48 & 85.94 & 87.87 & 407 \\
Goat manure & 5.39 & 94.61 & 86.08 & 13.92 & 2.196 & 13.73 & 4.40 & 49.93 & 22.74 & 67.96 & 401 \\
Buffalo manure & 3.32 & 96.68 & 56.08 & 43.92 & 1.464 & 9.15 & 4.30 & 32.52 & 22.22 & 42.63 & 269 \\
Babool woodchips & 4.09 & 95.91 & 99.28 & 00.72 & 0.179 & 1.12 & 3.00 & 57.58 & 321.1 & 95.16 & 429 \\
Mango woodchips & 5.09 & 94.91 & 89.28 & 10.72 & 0.149 & 0.94 & 3.25 & 51.78 & 345.4 & 85.09 & 389 \\
Babool sawdust & 4.33 & 95.67 & 98.83 & 01.17 & 0.153 & 0.96 & 5.75 & 57.32 & 374.6 & 92.12 & 442 \\
Mango sawdust & 2.59 & 97.41 & 52.03 & 47.97 & 0.135 & 0.84 & 3.15 & 30.18 & 223.5 & 48.04 & 234 \\
Pearl millet fodder & 4.88 & 95.12 & 89.52 & 10.48 & 0.774 & 4.84 & 5.25 & 51.92 & 67.09 & 79.43 & 406 \\
Proso millet Fodder & 5.97 & 94.03 & 61.00 & 39.00 & 0.787 & 4.92 & 10.3 & 35.38 & 44.95 & 45.78 & 315 \\
\hline
\end{tabular}

\begin{tabular}{lcc} 
& \multicolumn{3}{c}{ TABLE III: FORAGE FIBRE ANALYSI } \\
\hline & NDF & Cell contents \\
\hline Cow manure & 77 & 23 \\
Sugarcane waste & 80 & 20 \\
Goat manure & 66 & 34 \\
Buffalo manure & 74 & 26 \\
Babool woodchips & 88 & 12 \\
Mango woodchips & 87 & 13 \\
Babool sawdust & 85 & 15 \\
Mango sawdust & 88 & 12 \\
Pearl millet fodder & 70 & 30 \\
Proso millet fodder & 65 & 35 \\
\hline
\end{tabular}

The $\mathrm{pH}$ value of the influent ranged from 2.70-3.35. The $\mathrm{pH}$ increased to $7.50,7.10,6.25$ with goat manure, cow manure and buffalo manure respectively with maximum ten days retention time during second phase. Remaining cellulosic waste shows increase in $\mathrm{pH}$ maximum upto 5.32 with sugarcane waste with seven days retention (fig.3).

The influent sulphate values ranged from 4132 to 4960 $\mathrm{mg} / \mathrm{l}$ during both phase of the experiment. The sulphate concentration decreased by $1926.66,1950$ and $2195 \mathrm{mg} / \mathrm{l}$ with goat, buffalo and cow manure with maximum retention of 10 days respectively. Bioreactor with cellulosic waste decreased sulphate values ranged 3073.33 to $3500.25 \mathrm{mg} / \mathrm{l}$ with 10 days retention periods. All the manures efficiently removed sulphate. Percentage sulphate removal was shown in the figure 3.

In the experimental setup, chemical characterization of the selected organic substrates is given in table II. Carbon availability and nitrogen content are among the main factors affecting the efficiency of AMD treatment by SRB. Lignin and cellulose contents ranged from 7.4-23.8 percent (w/w) and 10-57.4 percent, respectively. Cow manure was with the lowest content of ligino-cellulosic materials, and babool woodchips and babool sawdust the highest. The content of easily degradable cell content in the ten organic substrates ranged between 34-35 percent in goat manure, pearl millet
OF ORGANIC WASTE (SINGLE SUBSTRATE)

\begin{tabular}{ccccc} 
ADF & $\begin{array}{c}\text { Hemi- } \\
\text { cellulose }\end{array}$ & Cellu-lose & Lignin & Silica \\
\hline 27.4 & 49 & 0 & 8.4 & 53.8 \\
52.4 & 28 & 37 & 7.4 & 3.2 \\
43.6 & 23 & 29.4 & 23.8 & 3.2 \\
42.2 & 32 & 15.6 & 9.6 & 32 \\
26.4 & 62 & 57.4 & 16.6 & Nil \\
27.8 & 59 & 44.6 & 20 & 7.6 \\
34.6 & 51 & 43.8 & 22.2 & Nil \\
21.2 & 67 & 25.6 & 14 & 39.2 \\
52.2 & 18 & 34.8 & 9 & 4 \\
61 & 4 & 28.2 & 6.6 & 4.2 \\
\hline
\end{tabular}

fodder (highest) and 12-13 percent (lowest) in babool woodchips and sawdust (table III).

$\mathrm{C} / \mathrm{N}$ ratio $(\mathrm{w} / \mathrm{w})$, based on total dry organic matter, ranged between 22.21 and 374.68. Although this method of $\mathrm{C} / \mathrm{N}$ computation is the most commonly used, it may not be appropriate because not all organic carbon is biodegradable and/or available for biological decomposition. Percent carbon observed maximum 57.58 in babool woodchips and lowest in the cow manure with 23.36. Gross energy calculated based on ether extractives, protein and total carbohydrate ranged between $184 \mathrm{Kcal} / 100 \mathrm{gm}$ in cow manure to $442 \mathrm{kcal} / 100 \mathrm{gm}$ in babool sawdust.

\section{CONCLUSION}

Selection of the organic substrates placed in SRBR has been based on descriptive characteristics. Goat, cow and buffalo manures exhibited high levels of sulphate and other contaminants in the initial operating period but may be lacked long-term sustainability. Similar findings are reported (Pinto et. al. (2001) (i.e. Chicken vs. Cow manure, or leaf vs. municipal compost).

It is essential to assess the chemical characteristics of organic matter and the relationship between different fractions and the effect on contaminants removal. Important characteristics like nitrogen/protein percent, cell content and carbon/nitrogen ratios are the good indicator of the initial 
startup of the bioreactors. Contaminants removed efficiently in the bioreactor containing manures having higher nitrogen/protein percent and cell content comparative to cellulosic wastes containing bioreactors. Manures containing bioreactors show the $\mathrm{C} / \mathrm{N}$ ratio between $22.22-23$. A $\mathrm{C} / \mathrm{N}$ ratio around 10 is generally considered suitable for biological degradation of complex substrates (Bechard et al, 1994). Higher ratio indicates excessive carbon or nitrogen deficiency, whereas lower ratio may suggest a lack of carbon. The results showed that the lower the content of liginin in the organic substrate, the higher its biodegradability and capacity for developing bacterial activity. These findings are similar to the Gibert et al, (2004).

Total carbohydrate and gross energy and Cpercentare directly not relate to the contaminants removal in the present study, but these all parameters define the higher percent of the organic carbon show the longevity of the substrates.

Wood materials (babool sawdust and woodchips, mango sawdust and woodchips) had lower nitrogen content ( $\mathrm{C} / \mathrm{N}$ ratio higher than 223) and less degradable carbon (Lignocellulose and lignin). Wood materials alone not efficiently workings in the single substrate bioreactors. Their less degradable carbon (lignocelluloses and lignin) may be an important factor in the longevity of the bioreactor due to continual supply of the organic carbon for longer time duration. Manures treat AMD during whole period of the observation, may be less effective with increased treatment time. Complex mixtures of the various cellulosic waste and organic waste based on their chemical characterization definitely useful in treating AMD, exhibited high levels of sulphate in the initial operating period and also have long-term sustainability.

\section{REFERENCES}

[1] American Public Health Association (APHA), 1992. Standard methods for the examination of water and waste water 18th edition. APHA, New York.

[2] Amos P.W., Younger P.L., 2003. Substrate characterization for a subsurface reactive barrier to peat colliery spoils leachate. Water Research, Vol. 37, pp. 108-120. http://dx.doi.org/10.1016/S0043-1354(02)00159-8

[3] Beaulieu S., Zagury G.J.,Deschenes L. and Samson R. 2000. Bioactivationandbioaugmentation of a passive reactor for acid mine drainage treatment. In R.K. Singhal and A.K. Mehrotra (ed.) Environmental issues and management of waste in energy and mineral production. A.A. Balkema, Rotterdam, the Netherlands. p. 533-537.

[4] Benner S., Blowes D.W., and Ptacek C.J., 1997. A full-scale porous reactive wall for prevention of acid mine drainage. Ground Water Monitoring and Remediation, pp. $99-107$.

http://dx.doi.org/10.1111/j.1745-6592.1997.tb01269.x

[5] Christensen, B., Laake, M., Lien, T., 1996. Treatment of acid mine water by surface reducing bacteria; results from a bench scale experiment. J. Wat. Res., Vol. 30 (7), pp. 1617-1624.

http://dx.doi.org/10.1016/0043-1354(96)00049-8

[6] Cocos I.A., Zagury G.J., Bernard C. and Samson R., 2002. Multiple factor design for reactive mixture selection for use in reactive walls in mine drainage treatment, Water Research, Vol. 32, pp. 167-177. http://dx.doi.org/10.1016/S0043-1354(01)00238-X

[7] Dvorak D. H., Hedin R. S., Edenborn H. M., and McIntire P. E. 1992. Treatment of metal-contaminated water using bacterial Sulphate reduction: results from pilot-scale reactors. Biotechnology and Bioengineering, Vol. 40, pp. 609. http://dx.doi.org/10.1002/bit.260400508

[8] Edenborn H.M. 2004. Use of poly (lactic acid) amendments to promote the bacterial fixation of metals in zinc smelter tailings. Bioresour. Technol., Vol. 92, pp. 111-119. http://dx.doi.org/10.1016/j.biortech.2003.09.004

[9] Gibert O., Pablo J. de, Cortina J.L., and Ayora C., 2004. Chemical characterization of natural organic substrates for biological mitigation of acid mine drainage. , Water Research., Vol. 38, pp. 4186-4196. http://dx.doi.org/10.1016/j.watres.2004.06.023

[10] Hulshoff Pol L.W., Lens P.N.L., Weijma J. \&Stams A.J.M., 2001. New developments in reactor and process technology for Sulphate reduction. Water Sci. Technol., Vol. 44, pp. 67-76

[11] Kaksonen A.H., Plumb J.J., Franzmann P.D. and J.A. Puhakaka. 2004b. Effects of hydraulic retention time and sulphide toxicity on ethanol and acetate oxidation in Sulphate reducing metal-precipitating fluidized-bed reactor. Biotechnol. Bioeng. Vol. 86, pp. 332-343. http://dx.doi.org/10.1002/bit.20061

[12] Mizuno O., Li Y.Y. and Noike T., 1998. The behavior of Sulphatereducing bacteria in acidogenic phase of anaerobic digestion. Water Res.,Vol. 32, pp. 1626-1634. http://dx.doi.org/10.1016/S0043-1354(97)00372-2

[13] Nagpal S., Chuichulcherm S., Livingston A. and Peeva L., $2000 \mathrm{~b}$. Ethanol Utilization by Sulphate-Reducing Bacteria: An Experimental and Modeling Study. Biotechnology and Bioengineering, Vol. 70, pp. 533-543.

http://dx.doi.org/10.1002/1097-0290(20001205)70:5<533::AIDBIT8>3.0.CO;2-C

[14] Pinto A.P., Wildeman T.R., and Gusek J.J., 2001. Remediation properties of materials to treat acid mine drainage water at a gold mine operation in Brazil. Paper presented at the 2001 national meeting of American Society for Surface Mining and Reclamation. Albuquerque, NM.

[15] Sheoran A.S., Sheoran V. and Choudhary R.P., 2010. Bioremediation of acid-rock drainage by sulphate-reducing prokaryotes: A review, Minerals Engineering 23(14), pp. 1073-1100 http://dx.doi.org/10.1016/j.mineng.2010.07.001

[16] Siefert J., Mutz M., 2001. Processing of leaf litter in acid waters of the post-mining landscape in lusatia, Germany, Ecological Engineering, Vol. 17, pp. 297-306. http://dx.doi.org/10.1016/S0925-8574(00)00146-4

[17] Tsukamoto T.K., H.A. Killion, G.C. Miller. 2004. Column Experiments for microbial treatment of acid mine drainage: low-temperature, low-pH and matrix investigations. Water Research Vol. 38, pp. 1405-1418. http://dx.doi.org/10.1016/j.watres.2003.12.012

[18] Van Soest P.J. Moore, L.A. 1965. New chemical methods for analysis of forages for the purpose of predicting nutritive value, Proceeding of IX International Grassland Congress, p.783.

[19] Van Soest P.J., Wine R.H., 1968. Determination of lignin and cellulose in Acid -detergent fiber with permanganate, Journal of the A.O.A.C., Vol. 51(4), pp.780-785. 